\title{
Highly Effective Water-Soluble Fluorescence Quenchers of Conjugated Polymer Thin Films in Aqueous Environments
}

\author{
Guy D. Joly, Lars Geiger, Steven E. Kooi, and Timothy M. Swager* \\ Department of Chemistry, Massachusetts Institute of Technology, 77 Massachusetts Avenue, Cambridge, \\ Massachusetts 02139
}

\section{Supporting Information}

General Procedures. All reactions were performed under an atmosphere of nitrogen or argon in ovendried or flame-dried round-bottomed flasks fitted with rubber septa and/or glass stoppers unless otherwise indicated. Stainless steel syringes or cannulae were used to transfer moisture sensitive liquids.

Materials. Commercial reagents were used as received. All solvents were spectral grade unless otherwise noted. Tetrahydrofuran and toluene used for synthetic purposes were obtained from J.T. Baker and purified by passing through a Glasscontour dry solvent system. Flash chromatography was performed using Sorbent silica 32-63, 60 Å. TLC was performed on Merck silica gel 60 F254 TLC glass plates and visualized with ultraviolet light or permanganate stain. Poly( $p$-phenyleneethynylene)s (PPEs) $\mathbf{1}^{1}$ and $\mathbf{3}^{2}$ were prepared according to literature procedures.

Instrumentation. Proton nuclear magnetic resonance ( $\left({ }^{1} \mathrm{H}\right.$ NMR) spectra and carbon nuclear magnetic resonance $\left({ }^{13} \mathrm{C}\right.$ NMR) spectra were recorded on Bruker Avance-400 (400 MHz) or Varian Inova-500 (500 $\mathrm{MHz}$ ) spectrometers. Chemical shifts for protons are reported in parts per million downfield from tetramethylsilane and are referenced to residual protium in the NMR solvent $\left(\mathrm{CHCl}_{3}: \delta 7.26\right.$; DMSO: $\delta$ 
2.50). Chemical shifts for carbon are reported in parts per million downfield from tetramethylsilane and are referenced to the carbon resonances of the solvent $\left(\mathrm{CDCl}_{3}: \delta 77.16\right.$; DMSO: 39.7). Data are presented as follows: chemical shift, integration, multiplicity $(\mathrm{br}=$ broad, $\mathrm{s}=$ singlet, $\mathrm{d}=$ doublet, $\mathrm{t}=$ triplet, $\mathrm{q}=$ quartet, $\mathrm{m}=$ multiplet), coupling constants in Hertz $(\mathrm{Hz})$, and assignment. Infrared (IR) spectra were obtained on a Perkin Elmer Spectrum 2000 FTIR spectrophotometer. Data are presented as follows: frequency of absorption $\left(\mathrm{cm}^{-1}\right)$ and intensity of absorption $(\mathrm{s}=$ strong, $\mathrm{m}=$ medium, $\mathrm{w}=$ weak $)$. Melting points were measured on a Mel-Temp apparatus and are uncorrected. High-resolution mass spectra (HRMS) were obtained at the Massachusetts Institute of Technology Department of Chemistry's Instrumentation Facility on a Bruker Daltonics APEX II 3 Tesla FT-ICR-MS using electrospray ionization (ESI). Polymer molecular weights were determined by gel permeation chromatography (GPC) versus polystyrene standards (Agilent Technologies, Inc.) using THF as the eluent at a flow rate of $1.0 \mathrm{~mL} / \mathrm{min}$ in a Hewlett Packard series 1100 GPC system equipped with three PLgel $5 \mu \mathrm{m} 10^{5}, 10^{4}, 10^{3}(300 \times 7.5 \mathrm{~mm})$ columns in series and a diode detector at $254 \mathrm{~nm}$. Molecular weights are reported relative to polystyrene standards purchased from Agilent Inc. UV/vis spectra of Langmuir-Blodgett films were recorded on a Cary $50 \mathrm{UV} / \mathrm{V}$ isible spectrophotometer and corrected for background signal with a clean glass cover slip. UV/vis spectra of solutions were obtained on an Agilent 8453 diode-array spectrophotometer. Emission spectra were acquired on a SPEX Fluorolog- $\tau 3$ fluorometer (model FL-321, $450 \mathrm{~W}$ xenon lamp). Solution measurements were made in $1 \mathrm{~cm}$ quartz cuvettes. Front-face detection was used for fluorescence measurements on LB films. All measurements on LB monolayers immersed in aqueous solution were performed using $1 \mathrm{~cm} \times 2 \mathrm{~cm}$ quartz cuvettes. Fluorescence quantum yields were determined by comparison to appropriate standards and are corrected for solvent refractive index and absorption differences at the excitation wavelength. Fluorescence quantum yields of monolayer LB films were determined relative to spin-cast films of $10^{-3} \mathrm{M} 9,10$-diphenylanthracene in polymethylmethacrylate. The refractive indecies of LB films were assumed to be the same. Fluorescence quantum yields in chloroform solutions were determined relative to equiabsorbing quinine sulfate solution. Time-resolved fluorescence measurements were acquired by exciting the samples with 170 femtosecond pulses at $390 \mathrm{~nm}$ from a Coherent RegA Ti:Sapphire amplifier. The resulting fluorescence was spectrally and temporally resolved with a Hamamatsu C4770 Streak Camera system. 
I. Langmuir-Blodgett Films. Langmuir-Blodgett films were prepared using a NIMA Technology, Ltd. 601 M LB trough equipped with a vertical dipping mechanism. Glass microscope cover slides (18 x 18 $\mathrm{mm}$ ) were used as LB substrates. Prior to use, the slides were cleaned by sonicating in detergent (20 min), rinsed with deionized water, sonicated in deionized water $(2 \times 15 \mathrm{~min})$, sonicated in aqueous potassium hydroxide $(3 \mathrm{M}, 1 \mathrm{~h})$, rinsed well with deionized water followed by rinsing with methanol. The slides were then dried in vacuo. To produce a hydrophobic surface, the clean slides were treated with 1,1,1,3,3,3hexamethyldisalazane in a sealed container for $12 \mathrm{~h}$ after which they were washed with hexanes and dried in vacuo. Polymer solutions in chloroform $(1 \mathrm{mg} / \mathrm{mL})$ were spread on the air-water interface. PPE LB monolayers were deposited at ca. $25 \mathrm{mN} / \mathrm{m}$ after three annealing cycles of compression and expansion. During monolayer deposition, the slides were oriented parallel to the direction of compression. After monolayer deposition, one side of the slide was wiped clean using a chloroform-saturated Kimwipe ${ }^{\circledR}$.

The method in which the Langmuir-Blodgett monolayers were prepared had little effect on sensitivity. Deposition Pressure: (experiments were performed using PPE 1 and viologen 7)

$25 \mathrm{mN} / \mathrm{m}: K_{\mathrm{SV}}=4.8 \times 10^{5}$

$14 \mathrm{mN} / \mathrm{m}: K_{\mathrm{SV}}=4.4 \times 10^{5}$

Hydrophobic vs. Hydrophilic Substrate: (experiments were performed using PPE 1 and viologen 7) Hydrophobic: $K_{\mathrm{SV}}=4.8 \times 10^{5}$ Hydrophilic: $K_{\mathrm{SV}}=4.7 \times 10^{5}$

Parallel vs. Perpendicular Dipping Direction: (experiments were performed using PPE 2 and viologen 7) Parallel: $K_{\mathrm{SV}}=1.2 \times 10^{6}$ Perpendicular: $K_{\mathrm{SV}}=8.9 \times 10^{5}$

Films thicker than a monolayer were too unstable in aqueous solution to perform quenching experiments.

II. Stern-Volmer Measurements on Langmuir-Blodgett Monolayers. The monolayer-coated cover slide was carefully taped into the inside of a large quartz cuvette $(1 \mathrm{~cm} \mathrm{x} 2 \mathrm{~cm})$ using one piece of tape (Kapton ${ }^{\circledR}$ w/ silicone tape) on each vertical side of the slide. The slide was secured such that the 
monolayer-coated side faced into solution and the uncoated side was pressed against the inside wall of the cuvette. The cuvette was then filled with the appropriate aqueous solution until the slide was completely immersed (usually 5-6.5 mL). Emission from the immersed slide was monitored and a quenching experiment was not performed until the slide was relatively stable as defined by a change (drop) in emission intensity of $5 \% / \mathrm{h}$ or less. Slides were usually stable within $3-6 \mathrm{~h}$ after being immersed in aqueous solution. During the equilibration process, the aqueous solution was thoroughly agitated approximately every 15-20 minutes. The quenching experiments were conducted by adding an aliquot of quencher (dissolved in the appropriate aqueous solution, usually in the concentration range from $1 \times 10^{-5}$ to $\left.1 \times 10^{-3} \mathrm{M}\right)$ to the monolayer-containing cuvette. The cuvette solution was thoroughly mixed and emission measurements were recorded at time points of 1 minute, 5 minutes, and 10 minutes for quenchers 4-7. The quenching response was usually steady between 5 and 10 minutes, and the 10 minute data were used for the reported quenching responses. Quencher 8 displayed a more sluggish kinetic response and typically took between 10 and 15 minutes to reach steady emission intensity. Therefore, for quencher $\mathbf{8}$, emission measurements were recorded at 1 minute, 5 minute, 10 minute, and 15 minute time points. The 15 minute data were used for the reported quenching responses for quencher 8. The Stern-Volmer data were acquired by integrating the emission spectra from $455-475 \mathrm{~nm}$. 


\section{PPE 2 Preparation.}
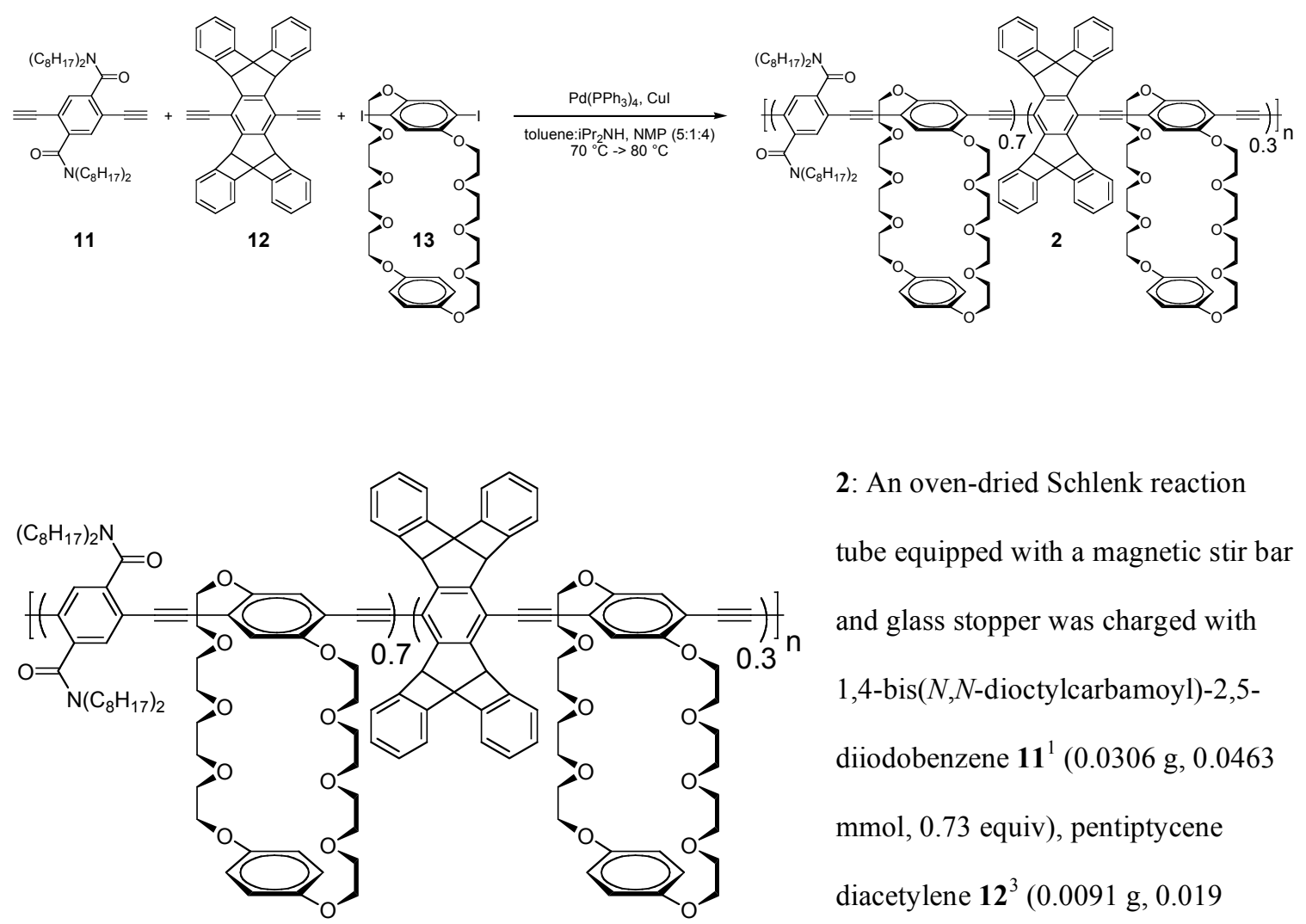

2: An oven-dried Schlenk reaction tube equipped with a magnetic stir bar and glass stopper was charged with 1,4-bis( $N, N$-dioctylcarbamoyl)-2,5diiodobenzene $11^{1}$ (0.0306 g, 0.0463 mmol, 0.73 equiv), pentiptycene diacetylene $12^{3}$ (0.0091 g, 0.019

mmol, 0.30 equiv), and crown ether $\mathbf{1 3}^{1}(0.0500 \mathrm{~g}, 0.0634 \mathrm{mmol}, 1.0$ equiv). The reaction vessel was taken into a glove box. Tetrakis(triphenylphosphine)-palladium(0) (0.004 g, $0.0035 \mathrm{mmol}, 0.05$ equiv) and copper(I) iodide ( $0.0006 \mathrm{~g}, 0.003 \mathrm{mmol}, 0.05$ equiv) were added under a nitrogen atmosphere. The reaction vessel was removed from the glove box and was then evacuated and backfilled with argon three times. Toluene:diisopropyl amine: $N$-methyl pyrrolidine $(5: 1: 4,1.75 \mathrm{~mL}$, sparged with argon for 30 minutes prior to use) was added. With stirring, the reaction was sealed and then evacuated briefly (for approximately 1-3 seconds) and backfilled with argon three times. The reaction was heated to $70{ }^{\circ} \mathrm{C}$. After $6 \mathrm{~h}$, the reaction was heated to $80{ }^{\circ} \mathrm{C}$. After an additional $66 \mathrm{~h}$, the reaction was cooled to $23{ }^{\circ} \mathrm{C}$ and diluted with chloroform $(75 \mathrm{~mL})$. The mixture was washed with deionized water $(75 \mathrm{~mL})$, an aqueous solution of ammonia $(8 \mathrm{M}, 75 \mathrm{~mL})$, deionized water $(75 \mathrm{~mL})$, an aqueous solution of hydrochloric acid (1M, $75 \mathrm{~mL})$, an aqueous solution of sodium bicarbonate $(75 \mathrm{~mL})$, and deionized water $(75 \mathrm{~mL})$. The organic solution was dried over sodium sulfate, filtered, and concentrated in vacuo to a volume of approximately $1.5 \mathrm{~mL}$. The chloroform solution was added dropwise to methanol $(50 \mathrm{~mL})$ with vigorous stirring to 
precipitate the polymer. The yellow solid was transferred to test tubes using methanol washes. The polymer was concentrated by centrifugation. The methanol solution was removed, replaced with fresh methanol, and re-centrifuged. This washing process was repeated. The yellow polymer was dried in vacuo to provide the product $2(0.045 \mathrm{~g}, 0.039 \mathrm{mmol}, 62 \%)$ as a yellow solid. The isolated polyer was determined to contain the amide-containing repeat and the pentiptycene-containing repeat in a ratio of 0.7:0.3 respectively by ${ }^{1} \mathrm{H}$ NMR. IR (thin film, $\mathrm{cm}^{-1}$ ) 3065 (w), 3043 (w), 2926 (s), 2856 (s), 1637 (s), 1508 (s), 1457 (s), 1232 (s), 1132 (s); ${ }^{1} \mathrm{H}$ NMR (500 MHz, $\mathrm{CDCl}_{3}$ ) $\delta$ 7.62-7.36 (ArH), 7.10-6.96 (ArH), 6.96-6.76 (ArH), 6.76-6.62 (ArH), 6.15-5.95 ( $\left.\mathrm{Ar}_{3} \mathrm{CH}\right), 4.61-4.51\left(\mathrm{CH}_{2}\right), 4.39-4.26\left(\mathrm{CH}_{2}\right), 4.26-3.40\left(\mathrm{OCH}_{2}\right), 3.24-$ $3.02\left(\mathrm{NCH}_{2}\right), 1.74-1.02\left(\mathrm{CH}_{2}\right), 0.92-0.78\left(\mathrm{CH}_{3}\right) ; \mathrm{GPC}(\mathrm{THF}, 1.0 \mathrm{~mL} / \mathrm{min}): \mathrm{M}_{\mathrm{n}}=3.83 \times 10^{4}, \mathrm{PDI}=3.3$. 


\section{Viologen Preparation.}
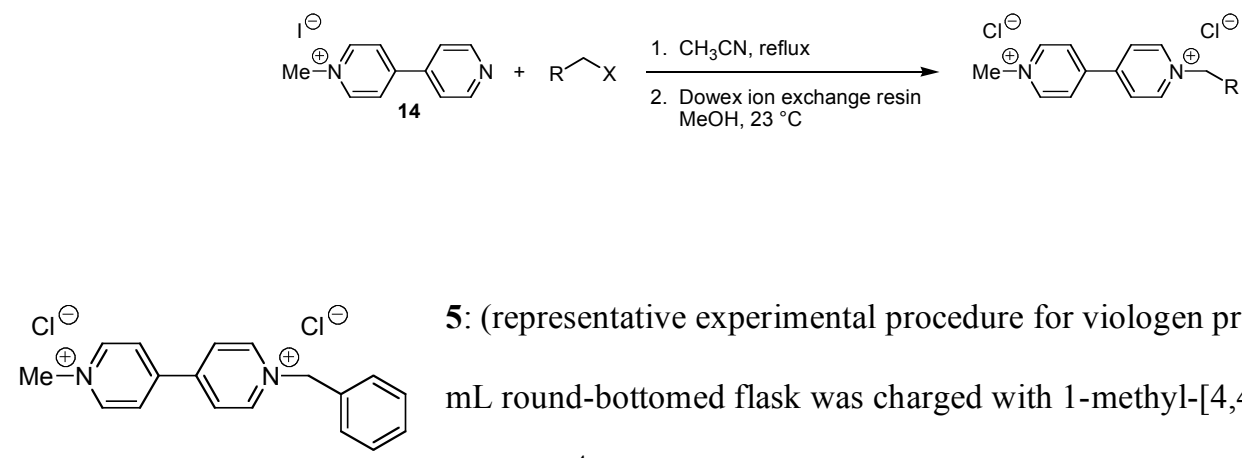

5: (representative experimental procedure for viologen preparation): A 200 $\mathrm{mL}$ round-bottomed flask was charged with 1-methyl-[4,4']bipyridylium iodide $14^{4}(0.298 \mathrm{~g}, 1.00 \mathrm{mmol}, 1.0$ equiv), acetonitrile $(75 \mathrm{~mL})$, and benzyl bromide ( $0.36 \mathrm{~mL}, 3.0 \mathrm{mmol}, 3.0$ equiv). The flask was equipped with a reflux condenser with a rubber septum. The reaction was placed under argon and then heated to reflux with stirring. After $14 \mathrm{~h}$, the heterogeneous reaction was cooled to room temperature. The heterogeneous mixture was vacuum filtered, and the reddish orange solid was washed with acetonitrile $(100 \mathrm{~mL})$. The reddish orange solid was transferred to an Erlenmeyer flask and dissolved in methanol $(100 \mathrm{~mL})$. Dowex 1x4-50 ion exchange resin (10 g, 1.2 MEQ/mL exchange capacity) was added, and the heterogeneous mixture was gently stirred. Within $5 \mathrm{~min}$, the solution color had changed from yellow to very pale yellow. After $16 \mathrm{~h}$, the reaction was vacuum filtered to remove the ion exchange resin and was concentrated in vacuo to provide the product $\mathbf{5}$ $(0.233 \mathrm{~g}, 0.699 \mathrm{mmol}, 70 \%)$ as a pale yellow solid. Decomposition at $276-279{ }^{\circ} \mathrm{C} ; \mathrm{IR}\left(\mathrm{KBr}, \mathrm{cm}^{-1}\right) 3043$ (m), 3022 (m), 2991 (s), 2946 (m), 2910 (s), 1643 (s), 1561 (s), 1516 (s), 1454 (s), 1361 (m), 1275 (m), 1245 (m), 1197 (m), 1172 (m); ${ }^{1} \mathrm{H}$ NMR (500 MHz, DMSO) $\delta 9.57$ (2H, d, J=7.1 Hz, ArH), 9.30 (2H, d, $J$ $=6.9 \mathrm{~Hz}, \operatorname{ArH}), 8.81(2 \mathrm{H}, \mathrm{d}, J=6.9 \mathrm{~Hz}, \operatorname{ArH}), 8.75(2 \mathrm{H}, \mathrm{d}, J=6.9 \mathrm{~Hz}, \operatorname{ArH}), 7.66-7.62(2 \mathrm{H}, \mathrm{m}, \operatorname{ArH})$, 7.51-7.44 (3H, m, ArH), 5.97 (2H, s, PyrNCH $\left.{ }_{2} \mathrm{Bn}\right), 4.44\left(3 \mathrm{H}, \mathrm{s}, \mathrm{CH}_{3}\right) ;{ }^{13} \mathrm{C} \mathrm{NMR}(100 \mathrm{MHz}, \mathrm{DMSO}) \delta$ 149.3, 148.4, 146.8, 146.0, 134.5, 129.7, 129.5, 129.2, 127.3, 126.4, 63.4, 48.2; HRMS (ESI) m/z for $\mathrm{C}_{18} \mathrm{H}_{17} \mathrm{~N}_{2}$ calcd. $[\mathrm{M}-2 \mathrm{Cl}-\mathrm{H}]^{+} 261.1386$, found 261.1386 .

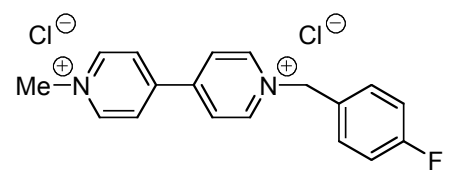

6: Reaction was performed on a $1.34 \mathrm{mmol}$ scale using 1-methyl[4,4’]bipyridylium iodide 14 (0.298 g, $1.00 \mathrm{mmol}, 1.0$ equiv), 4fluorobenzyl bromide $(0.375 \mathrm{~mL}, 3.01 \mathrm{mmol}, 3.0$ equiv), and acetonitrile $(75 \mathrm{~mL})$. The product was obtained after ion exchange using Dowex 1x4-50 ion exchange resin (10 g, 1.2 
$\mathrm{MEQ} / \mathrm{mL}$ exchange capacity $)$ in methanol $(100 \mathrm{~mL})$ to provide $6(0.180 \mathrm{~g}, 0.512 \mathrm{mmol}, 51 \%)$ as a pale orange solid. Decomposition at $270-275^{\circ} \mathrm{C}$; IR $\left(\mathrm{KBr}, \mathrm{cm}^{-1}\right) 3048$ (m), 2995 (s), 2913 (m), 1643 (s), 1563 (m), 1513 (s), 1462 (m), 1359 (m), 1228 (s), 1166 (m); ${ }^{1} \mathrm{H}$ NMR (500 MHz, DMSO) $\delta 9.55$ (2H, d, $J=7.1$ $\mathrm{Hz}, \operatorname{ArH}), 9.30(2 \mathrm{H}, \mathrm{d}, J=6.9 \mathrm{~Hz}, \mathrm{ArH}), 8.80(2 \mathrm{H}, \mathrm{d}, J=6.9 \mathrm{~Hz}, \operatorname{ArH}), 8.74(2 \mathrm{H}, \mathrm{d}, J=7.1 \mathrm{~Hz}, \operatorname{ArH})$, 7.77-7.72 (2H, m, ArH), 7.38-7.32 (2H, m, ArH), 5.95 (2H, s, PyrNCH $2 p-F B n), 4.44\left(3 \mathrm{H}, \mathrm{s}, \mathrm{CH}_{3}\right) ;{ }^{13} \mathrm{C}$ NMR (100 MHz, DMSO) $\delta 162.9(\mathrm{~d}, J=246.9 \mathrm{~Hz}), 149.3,148.3,146.8,145.9,131.9(\mathrm{~d}, J=8.4 \mathrm{~Hz})$, $130.8(\mathrm{~d}, J=3.1 \mathrm{~Hz}), 127.3,126.4,116.4(\mathrm{~d}, J=21.3 \mathrm{~Hz}), 62.5,48.2$; HRMS (ESI) $\mathrm{m} / \mathrm{z}$ for $\mathrm{C}_{18} \mathrm{H}_{16} \mathrm{FN}_{2}$ calcd. [M - $2 \mathrm{Cl}-\mathrm{H}]^{+}$279.1292, found 279.1301 .

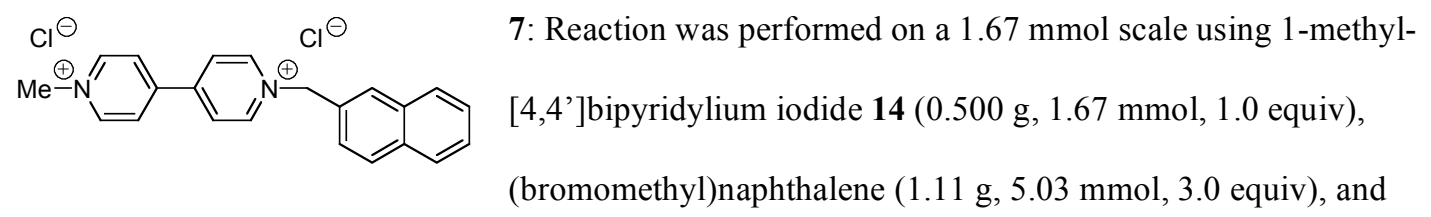
acetonitrile $(70 \mathrm{~mL})$. The product was obtained after ion exchange using Dowex 1x4-50 ion exchange resin (15 g, 1.2 MEQ/mL exchange capacity) in methanol $(125 \mathrm{~mL})$ to provide $7(0.380 \mathrm{~g}, 0.991 \mathrm{mmol}, 59 \%)$ as a pale yellow solid. Decomposition at 255-260 ${ }^{\circ} \mathrm{C}$; IR (KBr, $\left.\mathrm{cm}^{-1}\right) 3029$ (s), 2990 (s), 1636 (s), 1560 (m), 1506 (m), 1451 (m), 1352 (m), 1272 (w), 1231 (m), 1164 (m); ${ }^{1} \mathrm{H}$ NMR (500 MHz, DMSO) $\delta 9.64$ (2H, d, $J=7.1 \mathrm{~Hz}, \operatorname{ArH}), 9.31(2 \mathrm{H}, \mathrm{d}, J=6.9 \mathrm{~Hz}, \operatorname{ArH}), 8.83(2 \mathrm{H}, \mathrm{d}, J=6.9 \mathrm{~Hz}, \operatorname{ArH}), 8.76(2 \mathrm{H}, \mathrm{d}, J=7.1 \mathrm{~Hz}$, $\operatorname{ArH}), 8.20(1 \mathrm{H}, \mathrm{s}, \operatorname{ArH}), 8.02(1 \mathrm{H}, \mathrm{d}, J=8.7 \mathrm{~Hz}, \operatorname{ArH}), 7.99-7.93(2 \mathrm{H}, \mathrm{m}, \operatorname{ArH}), 7.72(1 \mathrm{H}, \mathrm{dd}, J=8.5,1.8$ $\mathrm{Hz}, \mathrm{ArH}), 7.63-7.58$ (2H, m, ArH), 6.15 (2H, s, PyrNCH $\mathbf{H}_{2}$ Naphthyl), 4.44 (3H, s, CH 3$) ;{ }^{13} \mathrm{C} \mathrm{NMR}(126$ MHz, DMSO) $\delta 149.1,148.2,146.6,145.9,133.0,132.7,131.7,129.1,128.6,128.0,127.7,127.2,127.0$, 127.0, 126.2, 125.9, 63.4, 48.0; HRMS (ESI) $\mathrm{m} / \mathrm{z}$ for $\mathrm{C}_{22} \mathrm{H}_{19} \mathrm{~N}_{2}$ calcd. $[\mathrm{M}-2 \mathrm{Cl}-\mathrm{H}]^{+}$311.1543, found 311.1540.

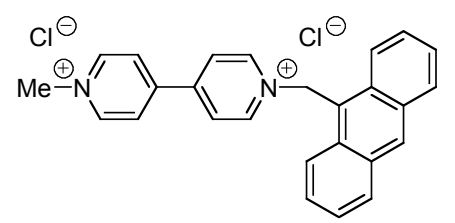

8: Reaction was performed on a $1.00 \mathrm{mmol}$ scale using 1-methyl[4,4']bipyridylium iodide 14 ( $0.300 \mathrm{~g}, 1.00 \mathrm{mmol}, 1.0$ equiv), 9(chloromethyl)anthracene (0.684 g, $3.02 \mathrm{mmol}, 3.0$ equiv), and 
acetonitrile $(100 \mathrm{~mL})$. The product was obtained after ion exchange using Dowex 1x4-50 ion exchange resin (10 g, 1.2 MEQ/mL exchange capacity) in methanol (125 mL) to provide $8(0.160 \mathrm{~g}, 0.369 \mathrm{mmol}$, $37 \%)$ as a red solid. Decomposition at $253-257^{\circ} \mathrm{C}$; IR $\left(\mathrm{KBr}, \mathrm{cm}^{-1}\right) 3032(\mathrm{~s}), 2880(\mathrm{w}), 1636(\mathrm{~s}), 1560(\mathrm{~m})$, 1506 (m), 1449 (s), 1376 (w), 1334 (w), 1223 (s), 1136 (m); ${ }^{1} \mathrm{H}$ NMR (400 MHz, DMSO) $\delta 9.23$ (2H, d, J $=6.8 \mathrm{~Hz}, \operatorname{ArH}), 9.13(2 \mathrm{H}, \mathrm{d}, J=6.6 \mathrm{~Hz}, \operatorname{ArH}), 8.97(1 \mathrm{H}, \mathrm{s}, \operatorname{ArH}), 8.66-8.61(4 \mathrm{H}, \mathrm{m}, \operatorname{ArH}), 8.47(2 \mathrm{H}, \mathrm{d}, J$ $=8.8 \mathrm{~Hz}, \operatorname{ArH}), 8.29(2 \mathrm{H}, \mathrm{d}, J=8.3 \mathrm{~Hz}, \operatorname{ArH}), 7.73-7.63(4 \mathrm{H}, \mathrm{m}, \operatorname{Ar} \mathbf{H}), 7.08(2 \mathrm{H}, \mathrm{s}$, PyrNCH ${ }_{2}$ Anthracene), 4.44 (3H, s, $\left.\mathrm{CH}_{3}\right) ;{ }^{13} \mathrm{C}$ NMR (100 MHz, DMSO) $\delta 149.4,148.6,146.9,145.2$, 131.8, 131.4, 130.0, 128.7, 127.2, 126.5, 126.1, 123.5, 121.8, 56.4, 48.3; HRMS (ESI) m/z for $\mathrm{C}_{26} \mathrm{H}_{21} \mathrm{~N}_{2}$ calcd. $[\mathrm{M}-2 \mathrm{Cl}-\mathrm{H}]^{+} 361.1699$, found 361.1691 .

\section{Stern-Volmer Plots for LB Films of PPE 1.}

The slopes shown on each graph (below) are for a single data set. The data reported in the manuscript (Figure 3) are averages of three or more measurements.

PPE 1 and viologen 4 in $20 \mathrm{mM}$ Tris buffer.

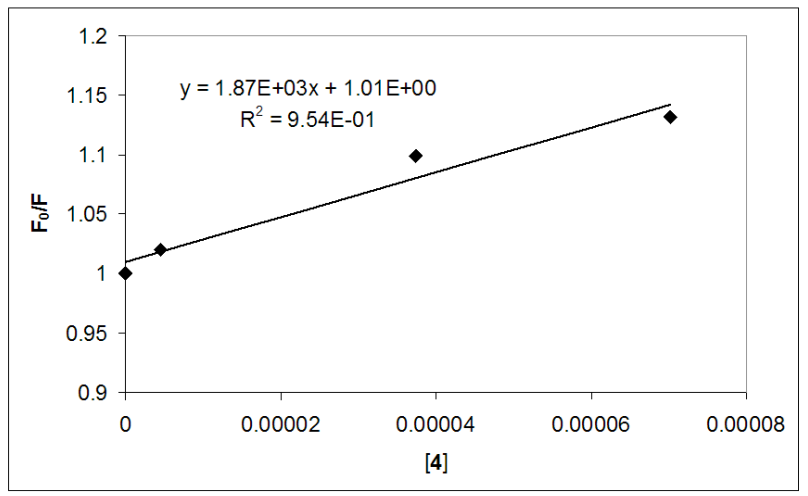


PPE $\mathbf{1}$ and viologen $\mathbf{5}$ in $20 \mathrm{mM}$ Tris buffer.

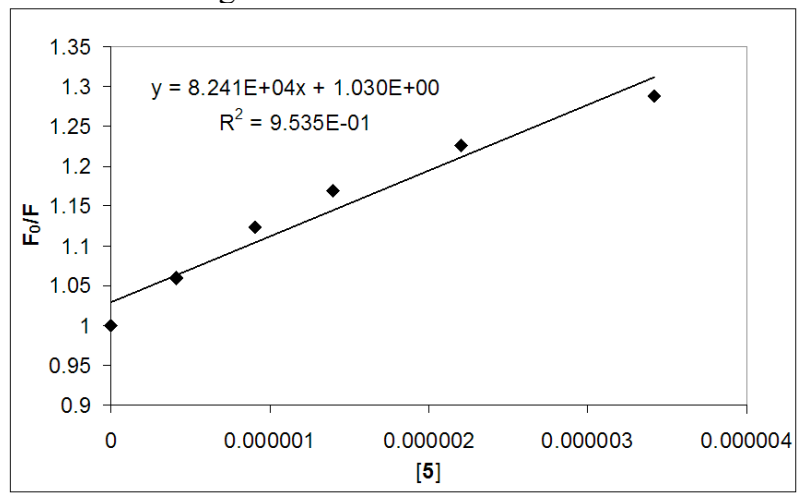

PPE 1 and viologen 6 in $20 \mathrm{mM}$ Tris buffer.

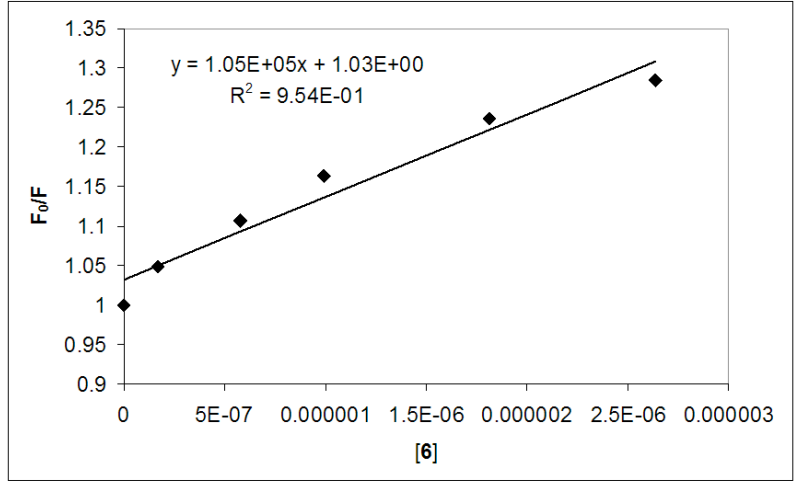

PPE 1 and viologen 7 in $20 \mathrm{mM}$ Tris buffer.

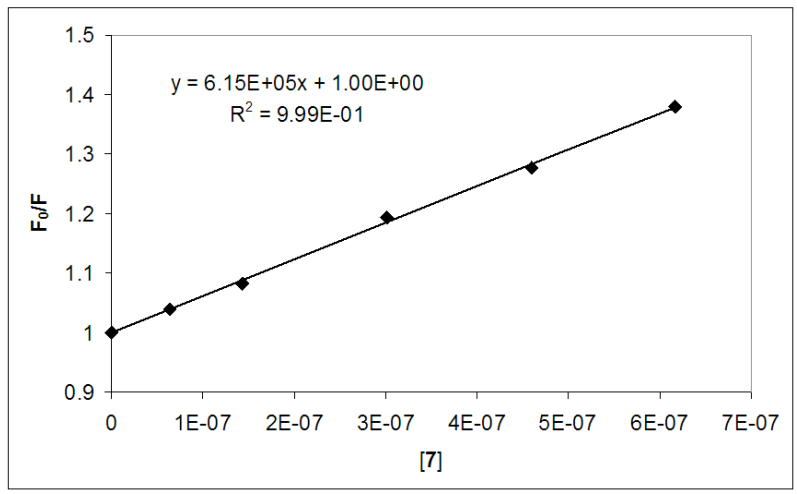


PPE 1 and viologen 8 in $20 \mathrm{mM}$ Tris buffer.

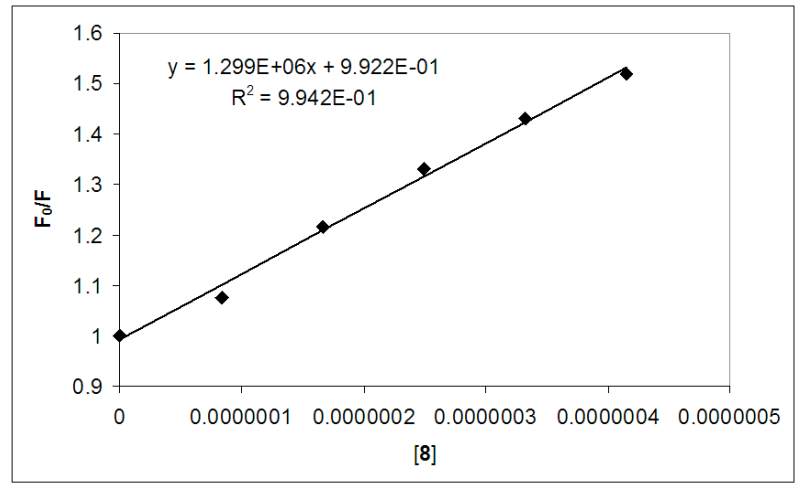

\section{Polymer Comparison.}

Polylmer fluorescence quenching by viologen 7 in $20 \mathrm{mM}$ Tris buffer.

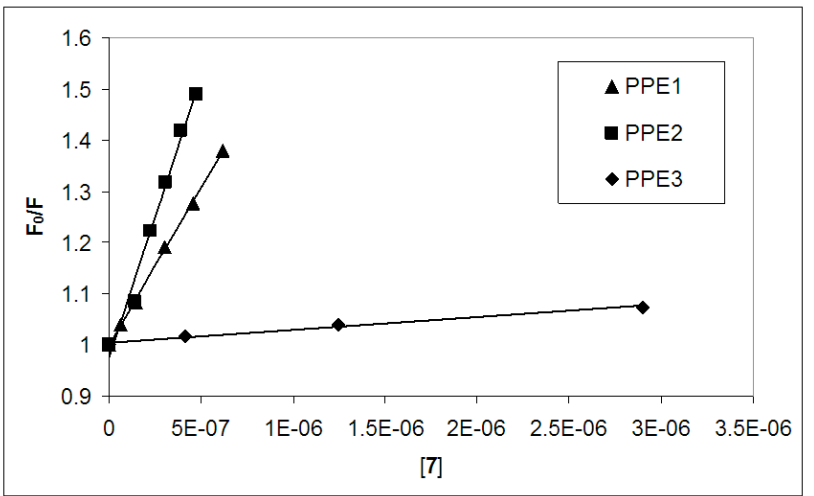

\section{Buffer Comparison.}

PPE 2 and viologen 7.

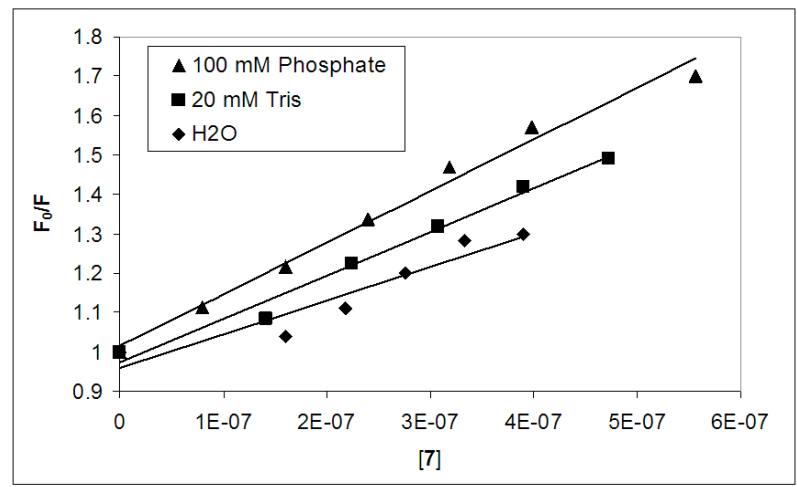




\section{References}

(1) Zhou, Q.; Swager, T. M. J. Am. Chem. Soc. 1995, 117, 12593.

(2) Kim, J.; Swager, T. M. Nature, 2001, 411, 1030.

(3) Yang, J.-S.; Swager, T. M. J. Am. Chem. Soc. 1998, 120, 11864.

(4) Feng, D.-J.; Li, X.-Q.; Wang, X.-Z.; Jiang, X.-K.; Li, Z.-T. Tetrahedron 2004, 60, 6137. 